\title{
Investigation of The Relationship Between Perception of Supervisor Support, Perceived School Effectiveness, Work Engagement, Job Satisfaction and Organizational Cynic Attitude of Teachers ${ }^{1}$
}

\begin{tabular}{|c|c|}
\hline \multicolumn{2}{|c|}{$\begin{array}{c}\text { Bahadır Gülbahar* } \\
\text { Department of Social Sciences and Turkish Education, Faculty of Education, Kırşehir Ahi } \\
\text { Evran University, Kirşehir, Turkey, ORCID: 0000-0002-7040-1593 }\end{array}$} \\
\hline Article history & The main purpose of this quantitative relational research is to test the \\
\hline $\begin{array}{l}\text { Received: } \\
03.04 .2020\end{array}$ & $\begin{array}{l}\text { theoretical framework within the structural equation model that if the } \\
\text { perceived supervisor support affects the perception of school }\end{array}$ \\
\hline $\begin{array}{l}\text { Received in revised form: } \\
14.05 .2020\end{array}$ & $\begin{array}{l}\text { effectiveness, engagement to work, job satisfaction, and organizational } \\
\text { cynical attitude. The sub-purpose of the study is to examine the } \\
\text { relationship between teachers' perceptions of these variables. Within the }\end{array}$ \\
\hline $\begin{array}{l}\text { Accepted: } \\
18.05 .2020\end{array}$ & $\begin{array}{l}\text { scope of the research, a structural equation model was established by } \\
\text { using the AMOS- } 25 \text { package program with the data collected from } 438\end{array}$ \\
\hline Key words: & teachers. Before constructing the structural equation model, \\
\hline $\begin{array}{l}\text { Supervisor support; } \\
\text { school effectiveness; } \\
\text { work engagement; } \\
\text { job satisfaction; } \\
\text { organizational cynic attitude }\end{array}$ & $\begin{array}{l}\text { confirmatory factor analysis was performed and the measurement } \\
\text { models for the scales used were verified. Fit index values of the } \\
\text { measurement models were found to be acceptable, therefore total score } \\
\text { was taken for each scale. "Perceived supervisor support" was determined } \\
\text { as independent variable and "perceived school effectiveness, } \\
\text { engagement to work, job satisfaction and organizational cynical attitude" } \\
\text { were determined as dependent variables and direct effect values of } \\
\text { independent variable on dependent variables were examined. Before } \\
\text { establishing the structural equation model, multiple normal distributions } \\
\text { of the scales were examined and "maximum likelihood" was chosen as } \\
\text { the parameter estimation method in order to ensure the normal } \\
\text { distribution assumption. The established structural equation model is } \\
\text { verified and it was concluded that perceived supervisor support } \\
\text { significantly predicted school effectiveness perception, work } \\
\text { engagement, job satisfaction and organizational cynical attitude. It was } \\
\text { also found that there were negative levels of negative relationships } \\
\text { between teachers' organizational cynical attitude and perceived } \\
\text { supervisor support, school effectiveness perception, work engagement } \\
\text { and job satisfaction. }\end{array}$ \\
\hline
\end{tabular}

\section{Introduction}

There are several variables that affect the quality of education. It can be said that supervisor support and teachers' perceptions about this support is a very important variable

\footnotetext{
${ }^{1}$ This study was presented as an oral presentation at the 3rd International Congress on Innovative Scientific Researches ( 3 to 6 October 2019, Adana / Turkey).

*Correspondency: bahadir.gulbahar@ahievran.edu.tr
} 
impacting the quality of education. It is of great importance that school principals consider teachers they work with as a valuable resource, support their development efforts, and prepare appropriate conditions for this to happen (Can, 2004). As a matter of fact, some studies reveal that management activities are the main factors that shape an employee's behavior (Guchiat, Paşamehmetoğlu \& Dawson, 2014; Román Calderón, Battistelli \& Odoardi, 2013). It is thereupon possible to say that teachers' perception that they are supported by the school principal will have many positive effects on them. According to social change theory, when employees feel supported by their managers, they tend to respond by showing good job performance (Melián-González, 2016). There are plentiful studies showing the relationship between perceived supervisor support and job performance (Park, Kang \& Kim, 2018; Paterson, Luthans \& Jeung, 2014; Talukder, Vickers \& Khan, 2018). According to Chiang and Hsieh (2012), perceived supervisor support has positive effects on job performance as well as job satisfaction. There are other studies showing the positive effects on job satisfaction (Ingersoll, 2001; Littrell, Billingsley \& Cross, 1994; Sahin, 2013; Sahin \& Dursun, 2009; Tillman \& Tillman, 2008). Argon (2014) found that perceived supervisor support would enable teachers to develop emotionally and behaviorally. It can be argued that this emotional and behavioral development of teachers will support teachers' engagement in their work, achieving job satisfaction and believing that their schools are effective. A bulk of studies in the literature (Ada, Akan, Ayik, Yildirim \&Yalcin, 2013; Afzal, Arshad, Saleem \& Farooq, 2019; Eisenberger, Stinglhamber, Vandenberghe, Sucharski \& Rhoades, 2002; Emhan, Kula \& Tongur, 2013; Erturk, Keskinkilic Kara \& Zafer Gunes, 2016; Li, Castaño \& Li, 2018;Ozdemir, 2010; Ozdemir Demirel, 2012; Sahin, 2013; Sahin \& Dursun, 2009; Tan, 2008; Yasar, Emhan $\&$ Ebere, 2014) support this claim through the findings and results they share.

It can also be argued that the perception of supervisor support will reduce or prevent the impact of low performance on organizational cynical attitude, which is seen as one of the most important reasons for not being able to connect to the organization. Supervisor support is indeed a key factor that enriches the working environment by reducing stress in the employee (Sloan, 2012). Employees naturally assume responsibility for the organization since they believe that their managers are empowered by the senior supervisors of the organization, and therefore that the supervisor's support and benefits are actually from the senior management, and that this support comes from the senior management (Neves, 2011; Rhoades, Eisenberger \& Armeli, 2001). Thence, supervisor support strengthens the employee's emotional ties with the organization (Stinglhamber \& Vandenberghe, 2003).

Teachers who perceive that they work in effective schools engage in their jobs, get satisfaction from their jobs and have positive attitudes towards their schools. This will result in an increase in their performance, productivity, and commitment to National Education Ministry and to the schools they work. In this direction, the professional and individual development efforts of these teachers will enhance and hence the relevant results will be attained. It can be uttered that there will be an improvement in the overall quality of teachers. These results will also improve the quality of education and the instruction given in schools. Quality education and instruction in schools will be positively reflected in the education system. Therefore, in this study, it is aimed to test the theoretical framework that the perceived supervisor support of teachers affects the perception of school effectiveness, work engagement, job satisfaction and organizational cynic attitude within the framework of structural equality model. For this purpose, the following hypothesis were developed for the structural relationships between variables:

$\mathrm{H}$ : Perceived supervisor support in teachers has an effect on the perception of school effectiveness, engagement in work, job satisfaction and organizational cynic attitude. 
The structural equation model established in accordance with the hypothesis of the research is visualized through the graph in Figure 1 below.

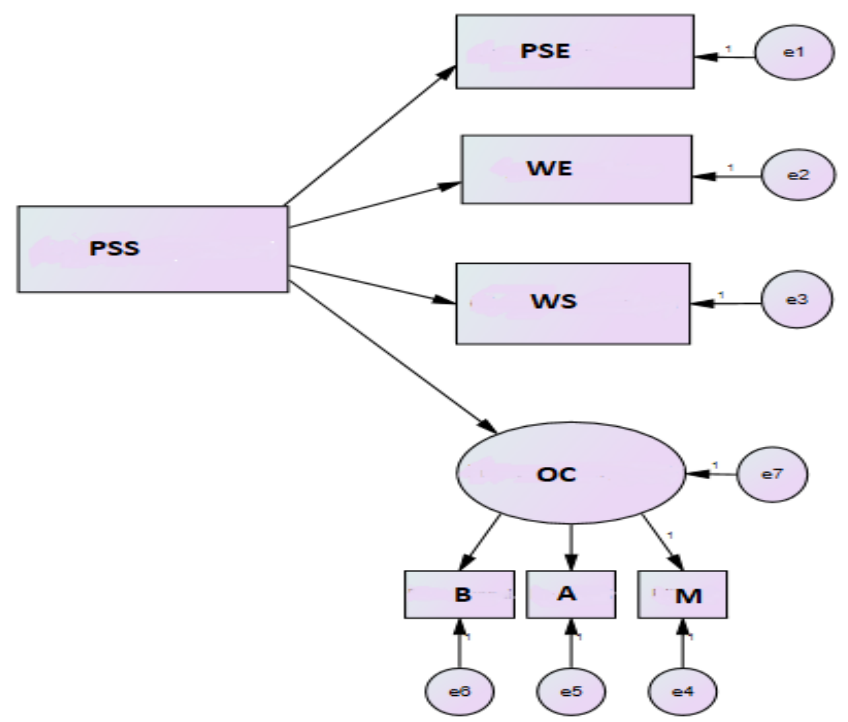

Figure 1. Graphical representation of the structural equation model.

Considering the main purpose of the research, it is understood that studying this is of crucial importance in particular for the practitioners viz. school principals and teachers. In the available literature, there are studies about the aforementioned variables in terms of certain demographic characteristics or about the relationship of these variables with some other related ones (e.g. Ada, Akan, Ayik, Yildirim \&Yalcin, 2013; Afzal, Arshad, Saleem \& Farooq, 2019; Alanoglu, 2019; Amasrali \& Aslan, 2017; Argon, 2014; Atik, Demirtas \& Aksoy, 2019; Bilgic, 2018; Emhan, Kula \&Tongur, 2013; Ercek, 2018; Erturk, Keskinkilic Kara \& Zafer Gunes, 2016; Kilic \& Burgaz, 2014; Li, Castaño \& Li, 2018; Ozdemir, 2010; Ozdemir Demirel, 2012; Ozkuk, 2017; Sarikaya, 2019; Tan, 2008; Yildirim, 2015). However, no study investigating the relationship between teachers' perceptions of supervisor support, perceptions of school effectiveness, engagement to work, job satisfaction, and organizational cynical attitudes analysed in a unified fashion was encountered. That said no study in which the relationship between these variables was investigated via putting forward a model was detected. These are believed to add onto the importance of the present study as to researchers' work whilst situating it amongst the others in the literature.

\section{Theoretical framework}

\section{Supervisor support}

It goes without saying that the most important goal of today's organizations is continuous development. Organizations can achieve this, as long as they can improve their employees and thusly achieve maximum efficiency. The high performance of employees, their desire to improve themselves and their efforts to realize this have a positive influence in the institution they work for. It would be fair to pronounce here that supervisor support is a fundamental variable that increases employee performance, job motivation as it encourages and improves them. Supervisor support is most commonly defined as the support provided by the employee's primary manager (Yoon \& Lim, 1999).

To that end it can be voiced that it is vital for the employee to feel high levels of supervisor 
support and thus it would be meaningful to determine the level of supervisor support perception. The concept of perceived supervisor support was referred to by Babin and Boles (1996) with a view to describing the level of perceived support of the employees' managers and is defined as the extent to which the employee feels the support the manager gives. Perceived supervisor support includes the dimensions of providing support to employees in their endeavour to achieve career goals, solve work-related problems, and balance private and business life (Cakmak \& Otluoglu, 2012; Turgut, 2011).

It might be speculated that the perception of supervisor support is also a significant factor for teachers. Teachers want support from school principals in different areas. Supervisor support appears in four sub-dimensions as "emotional support, valuation support, auxiliary support and informative support" (Makela, 2014). Accordingly, emotional support means that teachers are valued and appreciated by the school principal, their ideas are evaluated, and that the school principal offers them open communication opportunities. Auxiliary support means that the school administrator assists teachers in teaching and non-teaching activities and provides the necessary materials and resources for teaching (Makela, 2014). Valuation support is that the school principal empowers teachers with frequent and constructive feedback and gives clear information about what is required for effective teaching. Informative support means that the school principal provides teachers with practical information about effective teaching practices and informs them about how to improve classroom management (Littrell, Billingsley \& Cross, 1994).

Quality in education is influenced by countless parameters. With that being said the quality of teacher is the foremost among the factors that come into play for quality in education. A qualified teacher can be defined as a teacher who fulfills the responsibilities of effective teaching, guiding students, developing their schools, professional development, and collaboration with colleagues. Teachers' attitudes towards development is in fact a prominent variable regarding teacher quality. With this in mind it can be articulated that the teachers who are supported are successful in developing themselves and their schools. Teachers wish to witness that their efforts to develop the school are supported especially by the school principal. Such support makes it easier for teachers to draw conclusions about improving themselves and their schools.

Teachers may encounter several problems while performing their profession. These problems can negatively affect teachers' motivation, performance and engagement to work. The problems they face in their school can cause teachers to take a negative attitude towards their school. Some teachers can overcome professional problems on their own. Nevertheless, there are some who need support in doing so. Bearing in mind this school principal support becomes essential at this point.

At times due to the problems experienced by teachers in their private lives, issues like low performance, reluctance and absenteeism can be observed. These reasons actually decrease the efficiency of teaching. The school principal should also be able to help teachers solve their private life problems when/if necessary.

\section{Effective school}

Organizations should make high efforts to reach their goals and meet expectations and try to develop themselves in achieving desired outcomes in both of these areas. Failure of an organization in doing this may result in negative perception in employees as well as those 
benefiting from the products and services provided i.e. stakeholders. An effective organization can herein be identified as one with a high level of achievement of its objectives, ensuring a high level of satisfaction of those benefiting from its services or products, and one that is successful in meeting expectations. In a similar vein an effective school can be pinpointed as an institution that wholly fulfills the objectives and assumed functions, assures the development of students in all aspects and prepares them for their future roles, provides appropriate learning environments for this purpose and meets the expectations of all stakeholders (Balci, 2011; Sisman \& Turan, 2005).

According to Ozdemir (2000), an effective school is a school where all the stakeholders 'happiness and development are based on, where students, teachers and the environment can form a whole, where students' cognitive, affective, psychomotor, social and aesthetic developments are provided, and an optimum learning environment is created'. In order to talk about the effectiveness of a school, apparently it is necessary to diagnose that students experience a high level of learning and develop their behaviors as desired (Dos, 2013).

It is well known that school principals possess a big role in creating effective schools. In this context, it is important that they also carry the role of leadership and more specifically instructional leadership. Instructional leadership requires school heads to fulfill their roles in providing the necessary school resources, preparing the ground for effective learning and teaching at school, and predicting high levels of success for all students (Sisman, 2012). As a result of the review of the literature, it was determined that school principals in effective schools display a determined and goal oriented leadership behavior, a participatory approach and take the stance of a professional leadership (Sammons, Hillman \& Mortimore, 1995).

\section{Work engagement}

Burnout is a negative mental process that is critical for the efficiency of the organization. The concept of burnout, which represents a social problem related to the business environment, is also a negative situation for the organization. Over time, the interest of researchers has shifted from burnout to work engagement with the opposite of this notion (Bal, 2009, Mosadeghrad \& Ferdosi, 2013; Ravikumar, 2013; Schaufeli, 2015). In later studies, it was understood that burnout and work engagement were not different from each other but very different concepts (Bal, 2009).

Work engagement may be explained in general terms as the dedication of employees to their roles in their jobs physically, cognitively and emotionally; their commitment to work, their positive emotions and enthusiasm (May, Gilson \& Harter, 2004; Roberts \& Davenport, 2002). When the definition is scrutinized, it is understandable that CEOs see inability to engage work as one of the five most important problems of the management process (Sarkisian, Bhate \& Lee, 2011). Again, based on the above definition it can be thought that work engagement is a highly significant concept in terms of employee performance and productivity.

\section{Job satisfaction}

It is possible to define job satisfaction as the sum of the emotional reactions of the employee to the organization and the job he / she is doing (Acar, 2016; Hackman \& Oldham, 1976; Yapicikardesler, 2007). An employee with a job that does not suit their interests and abilities may not be satisfied with their job. Owing to dissatisfaction with work, perception of worthlessness, boredom, relaxation and tension in life ties may also occur (Ada, 2014). Low 
job satisfaction affects and weakens not only the individual but also the organization itself (Handsome, 2009).

It is plausible to divide the factors affecting the level of satisfaction obtained from work into two; being individual and organizational factors. Gender, age, educational background, professional seniority, expectations from the future and perception of competence can be enlisted as individual factors. The quality of work, working conditions and colleagues, salary, promotion, reward system, social possibilities, managers and management's approach are among the organizational factors (Bogler, 2002; Dugguh \& Ayaga, 2014; Ma \& Mcmillan, 1999). Through some studies on teachers, it was figured out that the support given by the manager is also influential in job satisfaction (Ingersoll, 2001; Littrell, Billingsley \& Cross, 1994; Tillman \& Tillman, 2008).

Research results on teachers' job satisfaction reveal that the frequency of continuing work increases as job satisfaction increases. According to the results of these studies, as the job satisfaction decreases, the perception of wearing out, the desire to quit and the frequency of absenteeism increase (Makela, 2014; Miles, 2010). It is believed that teachers with high level of job satisfaction provide more quality education and instruction, and whence their students are relatively more successful (Demirtas, 2010).

\section{Organizational cynicism}

Organizational cynicism, which prevents employees from being connected to their institutions, causes them to perform poorly. It is associated with negative attitude towards individuals, belief in the lack of honesty principles in their organizations, humiliating and brutal criticism of their organizations (Dean, Brandes \& Dharwadker, 1998). Andersson (1996) describes organizational cynicism as negative attitudes and behaviors such as skepticism, distrust, frustration, anger, and hopelessness towards individuals, groups, ideologies, social skills or institutions. According to Abraham (2000), organizational cynicism stems from the negative attitudes of individuals toward the organization they work at. These attitudes cause employees to develop negative feelings towards their organizations and to criticize their organizations mercilessly. In light of the information provided, it is tenable to state that organizational cynical attitude has a negative relationship with variables that positively affect the performance and productivity of employees. Considering teachers, it can be claimed that organizational cynical attitude is a factor that can decrease the quality of education.

\section{Method}

\section{Research design}

The main purpose of this quantitative relational research is to test the theoretical framework within the structural equation model that whether the perceived supervisor support affects the perception of school effectiveness, engagement to work, job satisfaction, and organizational cynical attitude. The sub-purpose of the study is to examine the relationship between teachers' perceptions of these variables. The structural equation model is a comprehensive statistical method used to test models with hypotheses for causal and correlational relationships between observed and latent variables (Hoyle, 1995). The purpose of structural equation modelling studies is to reveal whether the predetermined relationship patterns are verified by the obtained data. Prior to testing with data, the theoretical basis of the model should be established precisely (Simsek, 2007). 
Figure 2 shows the structural equation model of this study, while Figure 3 exhibits the measurement model.

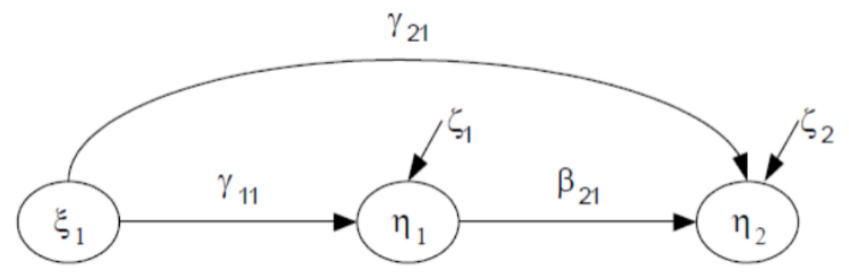

Figure 2. Structural equation model.

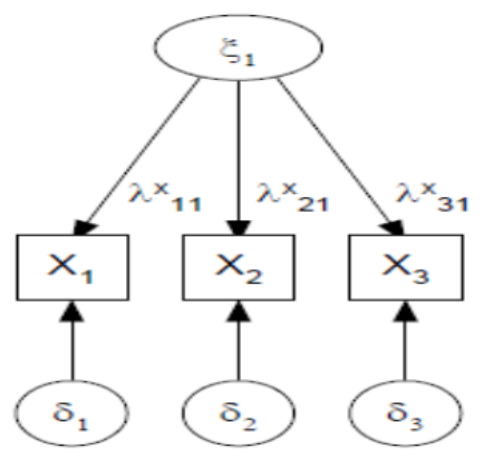

Figure 3. Measurement model.

\section{Participants}

The working universe of the current study consists of 1186 teachers working in high schools in Kirsehir in the academic year 2019-2020. In the research, simple random sampling method was used as sampling method. In accordance with that, the sample consists of 438 teachers in the research universe. Of these teachers, 243 (55.5\%) are women and 195 (44.5) are men. The distribution of teachers by gender is presented in Table 1.

Table 1. Distribution of teachers by gender.

\begin{tabular}{lcc}
\hline & $\mathbf{n}$ & $\mathbf{\%}$ \\
Female & 243 & 55,5 \\
Male & 195 & 44,5 \\
Total & 438 & 100,0 \\
\hline
\end{tabular}

\section{Instruments}

\section{Perceived supervisor support scale}

Kottke and Sharafinski (1988) developed the abovementioned scale. Ozdemir (2010) translated it into Turkish and adapted it to the educational environment. The scale consists of one dimension and 14 items. In the reliability study conducted for the scale, it was found that 14 items were collected under one factor, total variance was ,71, and Cronbach Alpha coefficient of the items ranged between ,96 and that factor loads are between ,58 and ,90.Table 2 indictaes the fit index values for the measurement model established to verify the structure of the scale developed previously with the data collected in this research. 
Table 2. Fit index values of the measurement model related to perceived supervisor support scale.

\begin{tabular}{llll}
\hline Fit Index & $\begin{array}{l}\text { Confirmatory Factor } \\
\text { Analysis }\end{array}$ & Good Fit Criteria & Acceptable Fit Criteria \\
\hline$\chi^{2 /}(\mathrm{df})$ & $260,24 /(71)=$ & $0 \leq \chi^{2} \leq 3$ & $3<\chi^{2} \leq 5$ \\
RMSEA & 3,67 & $0 \leq \mathrm{RMSEA} \leq 0,05$ & $0,05<\mathrm{RMSEA} \leq 0,08$ \\
TLI/NNFI & 0.078 & $0,97 \leq \mathrm{TLI} \leq 1,00$ & $0,95 \leq \mathrm{TLI}<0,97$ \\
CFI & 0.96 & $0,97 \leq \mathrm{CFI} \leq 1,00$ & $0,95 \leq \mathrm{CFI}<0,97$ \\
NFI & 0.97 & $0,95 \leq \mathrm{NFI} \leq 1,00$ & $0,90 \leq \mathrm{NFI}<0,95$ \\
AGFI & 0.96 & $0,90 \leq \mathrm{AGFI} \leq 1,00$ & $0,85 \leq \mathrm{AGFI}<0,90$ \\
GFI & 0,88 & $0,95 \leq \mathrm{GFI} \leq 1,00$ & $0,90 \leq \mathrm{GFI}<0,95$ \\
\hline
\end{tabular}

Table 2 shares that the fit index values are good or acceptable (Byrne, 2013; SchermellehEngel, Moosbrugger \& Müller, 2003). It appears that the model has been verified.

\section{Perceived school effectiveness scale}

Mott (1972) developed this very scale so as to measure the effectiveness of hospitals. First, Miskel et al. (1979) and then by Hoy et al. $(1985 ; 1991 ; 1996)$ adapted the scale to schools. Yildirim (2015) adapted it to Turkish. It consists of one factor and 8 items. The last version of the scale used in this study was created by Hoy (2014). It was calculated that the load values of the items ranged from ,629 to ,772. In the correlation analysis conducted to reveal the language equivalence of the scale, the correlation coefficient between the total scores of the English and Turkish scales was found to be significant at a significance level of 0.01 as ,708. Cronbach Alpha internal consistency coefficient of the scale is ,866. The test-retest reliability coefficient of the scale is, 847 . Findings obtained from the analyses indicated that the adapted scale demonstrated psychometric properties that could be used easily in Turkey. Table 3 points to the fit index values for the measurement model established to verify the structure of the scale developed previously with the data collected in this research.

Table 3. Fit index values of the measurement model related to perceived school effectiveness scale.

\begin{tabular}{|c|c|c|c|}
\hline Fit Index & $\begin{array}{l}\text { Confirmatory } \\
\text { Factor Analysis }\end{array}$ & Good Fit Criteria & Acceptable Fit Criteria \\
\hline$\chi^{2 /(\mathrm{df})}$ & $\begin{array}{l}46,81 /(14)= \\
3,34\end{array}$ & $0 \leq \chi^{2} \leq 3$ & $3<\chi^{2} \leq 5$ \\
\hline RMSEA & 0.073 & $0 \leq \mathrm{RMSEA} \leq 0,05$ & $0,05<$ RMSEA $\leq 0,08$ \\
\hline TLI/NNFI & 0.97 & $0,97 \leq \mathrm{TLI} \leq 1,00$ & $0,95 \leq \mathrm{TLI}<0,97$ \\
\hline CFI & 0.99 & $0,97 \leq \mathrm{CFI} \leq 1,00$ & $0,95 \leq \mathrm{CFI}<0,97$ \\
\hline NFI & 0.98 & $0,95 \leq \mathrm{NFI} \leq 1,00$ & $0,90 \leq \mathrm{NFI}<0,95$ \\
\hline AGFI & 0,93 & $0,90 \leq \mathrm{AGFI} \leq 1,00$ & $0,85 \leq \mathrm{AGFI}<0,90$ \\
\hline GFI & 0,97 & $0,95 \leq \mathrm{GFI} \leq 1,00$ & $0,90 \leq \mathrm{GFI}<0,95$ \\
\hline
\end{tabular}

Table 3 communicates that the fit index values are good or acceptable (Byrne, 2013; Schermelleh-Engel, Moosbrugger \& Müller, 2003). It appears that the model has been verified.

\section{Engagement to work scale}

The scale was developed in 2003 by Schaufeli and Bakker. According to the factor analysis, it was found that the scale could be explained by two factors. These two factors explain 
$58.91 \%$ of the total variance of the scale. The values obtained indicate that the scale has a high validity. Ozkalp and Meydan (2015) adapted it to Turkish. This version consists of 9 items in a 5-point Likert type and of a single factor. In order to measure the reliability of the scale, Cronbach Alpha coefficient was found to be ,844. Table 4 shows the fit index values for the measurement model established to verify the structure of the scale developed previously with the data collected in this research.

Table 4. Fit index values of the measurement model related to engagement to work scale.

\begin{tabular}{|c|c|c|c|}
\hline Fit Index & $\begin{array}{l}\text { Confirmatory } \\
\text { Factor Analysis }\end{array}$ & Good Fit Criteria & Acceptable Fit Criteria \\
\hline$\chi^{2 /(\mathrm{df})}$ & $\begin{array}{l}80,33 /(24)= \\
3,35\end{array}$ & $0 \leq \chi^{2} \leq 3$ & $3<\chi^{2} \leq 5$ \\
\hline RMSEA & 0.073 & $0 \leq \mathrm{RMSEA} \leq 0,05$ & $0,05<$ RMSEA $\leq 0,08$ \\
\hline TLI/NNFI & 0.96 & $0,97 \leq \mathrm{TLI} \leq 1,00$ & $0,95 \leq \mathrm{TLI}<0,97$ \\
\hline $\mathrm{CFI}$ & 0.98 & $0,97 \leq \mathrm{CFI} \leq 1,00$ & $0,95 \leq \mathrm{CFI}<0,97$ \\
\hline NFI & 0.97 & $0,95 \leq \mathrm{NFI} \leq 1,00$ & $0,90 \leq \mathrm{NFI}<0,95$ \\
\hline AGFI & 0,93 & $0,90 \leq \mathrm{AGFI} \leq 1,00$ & $0,85 \leq \mathrm{AGFI}<0,90$ \\
\hline GFI & 0,96 & $0,95 \leq \mathrm{GFI} \leq 1,00$ & $0,90 \leq \mathrm{GFI}<0,95$ \\
\hline
\end{tabular}

Table 4 shows that the fit index values are good or acceptable (Byrne, 2013; SchermellehEngel, Moosbrugger \& Müller, 2003). It appears that the model has been verified.

\section{Job satisfaction scale}

Ho and Au developed that scale (2006). Demirtas (2010) adapted it to Turkish (2010). The scale comprises five items. It was found out that the load values of the items of the scale, which were analyzed again by Demirtas and Alanoglu (2015), vary between ,68 and ,90. The fit index of the model suggests that the fit of the model is good. The scale explained $63.71 \%$ of the total variance (eigen value $=3.19$ ) and consisted of one dimension. The load values of the scale items ranged from, 75 to, 82 . The internal consistency coefficient of the scale was found to be ,86. Table 5 adduces the fit index values for the measurement model established to verify the structure of the scale developed previously with the data collected in this research

Table 5. Fit index values of the measurement model related to job satisfaction scale.

\begin{tabular}{llll}
\hline Fit Index & $\begin{array}{l}\text { Confirmatory } \\
\text { Factor Analysis }\end{array}$ & Good Fit Criteria & Acceptable Fit Criteria \\
\hline$\chi^{2 /(\mathrm{df})}$ & $22,24 /(5)=$ & $0 \leq \chi^{2} \leq 3$ & $3<\chi^{2} \leq 5$ \\
RMSEA & 4,45 & $0 \leq \mathrm{RMSEA} \leq 0,05$ & $0,05<\mathrm{RMSEA} \leq 0,08$ \\
TLI/NNFI & 0.074 & $0,97 \leq \mathrm{TLI} \leq 1,00$ & $0,95 \leq \mathrm{TLI}<0,97$ \\
CFI & 0.97 & $0,97 \leq \mathrm{CFI} \leq 1,00$ & $0,95 \leq \mathrm{CFI}<0,97$ \\
NFI & 0.98 & $0,95 \leq \mathrm{NFI} \leq 1,00$ & $0,90 \leq \mathrm{NFI}<0,95$ \\
AGFI & 0.98 & $0,90 \leq \mathrm{AGFI} \leq 1,00$ & $0,85 \leq \mathrm{AGFI}<0,90$ \\
GFI & 0,94 & $0,95 \leq \mathrm{GFI} \leq 1,00$ & $0,90 \leq \mathrm{GFI}<0,95$ \\
\hline
\end{tabular}

Table 5 shows that the fit index values are good or acceptable (Byrne, 2013; SchermellehEngel, Moosbrugger \& Müller, 2003). It appears that the model has been verified.

\section{Organizational cynicism scale}

Brandes et al. (1999) developed the scale mentioned above. Kalagan (2009) adapted it to Turkish. The scale consists of 13 items and is a 5-point Likert-type scale consisting of 3 subdimensions. According to the exploratory factor analysis, the factor loadings of the items in the 
"cognitive cynicism" dimension consisting of five items varied between ,763 and ,819, and the variance ratio explained by the dimension was $29.09 \%$. In the "affective cynicism" dimension consisting of four items, it was computed that the factor loads of the items varied between ,737 and ,885 and the variance ratio explained by the dimension was $27.177 \%$. It was spotted that factor loadings of "behavioral cynicism" items consisting of four items ranged between ,668 and, 895 , and the variance ratio explained by the dimension was $22.398 \%$. The Cronbach Alpha internal consistency coefficients of the scale were specified as ,913 for the cognitive dimension, ,948 for the affective dimension, ,866 for the behavioral dimension ,and,931 for the whole scale. Table 6 shows the fit index values for the measurement model established to verify the structure of the scale developed previously with the data collected in this research.

Table 6. Fit index values of the measurement model related to organizational cynicism scale.

\begin{tabular}{llll}
\hline Fit Index & $\begin{array}{l}\text { Confirmatory Factor } \\
\text { Analysis }\end{array}$ & Good Fit Criteria & Acceptable Fit Criteria \\
\hline$\chi^{2 /(\mathrm{df})}$ & $174,54 /(61)=$ & $0 \leq \chi^{2} \leq 3$ & $3<\chi^{2} \leq 5$ \\
RMSEA & 2,86 & $0 \leq \mathrm{RMSEA} \leq 0,05$ & $0,05<\mathrm{RMSEA} \leq 0,08$ \\
TLI/NNFI & 0.065 & $0,97 \leq \mathrm{TLI} \leq 1,00$ & $0,95 \leq \mathrm{TLI}<0,97$ \\
CFI & 0.97 & $0,97 \leq \mathrm{CFI} \leq 1,00$ & $0,95 \leq \mathrm{CFI}<0,97$ \\
NFI & 0.98 & $0,95 \leq \mathrm{NFI} \leq 1,00$ & $0,90 \leq \mathrm{NFI}<0,95$ \\
AGFI & 0.96 & $0,90 \leq \mathrm{AGFI} \leq 1,00$ & $0,85 \leq \mathrm{AGFI}<0,90$ \\
GFI & 0,92 & $0,95 \leq \mathrm{GFI} \leq 1,00$ & $0,90 \leq \mathrm{GFI}<0,95$ \\
\hline
\end{tabular}

Table 6 shows that the fit index values are good or acceptable (Byrne, 2013; SchermellehEngel, Moosbrugger \& Müller, 2003). It appears that the model has been verified.

\section{Data analysis}

The data were processed in the SPSS-25 statistics program. The extreme values were examined by examining the box plot chart of the data. The lost data were also checked, and then the mahalonobis distances of the data distribution were looked into. Accordingly, no inappropriate data was found. AMOS-25 package program was resorted to to be able to analyze the data collected from 438 teachers, and structural equation modeling analyses were carried out. Goodness of fit indices related to structural model and measurement model were measured. The criteria for the "RMSEA, TLI, CFI, NFI, AGFI, GFI" fit indices considered for this assessment were determined by Schermelleh-Engel, Moosbrugger and Müller (2003) and the criterion for the " $\chi 2$ " fit index was determined by Byrne (2013). Good fit criteria are as follows:

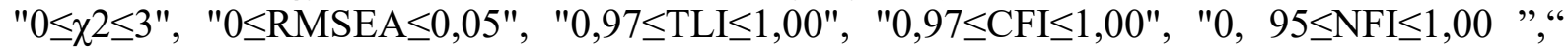
$0,90 \leq \mathrm{AGFI} \leq 1,00$ "and" $0,95 \leq \mathrm{GFI} \leq 1,00$ ". Acceptable fit criteria are as follows: " $3<\chi 2 \leq 5$ ",

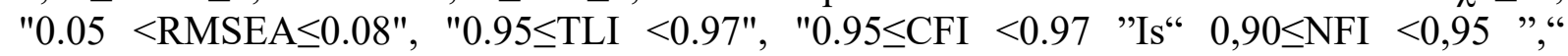
$0,85 \leq$ AGFI $<0,90$ "and" $0,90 \leq$ GFI $<0,95$ ". Direct effect and indirect effect paths related to structural equation model are defined and the level of regression effects are delved into. The relationship between the scores obtained from the scales used within the scope of the research and the scores obtained from the overall and sub-factors of the Organizational Cynicism Scale was dwelled upon using Pearson correlation analysis, which is a parametric test for the skewness and kurtosis values of the points are between -1 and +1 and Levene homogeneity test is meaningless compared to $\mathrm{p}<, 05$, that is, it is homogeneously distributed. 


\section{Findings}

\section{Main problem}

The main problem in the research is this: "Does the perception of supervisor support in teachers have an effect on the perception of school effectiveness, engagement in work, job satisfaction and organizational cynic attitude?"

Graphical representation of the established structural equation model can be seen in Figure 4.

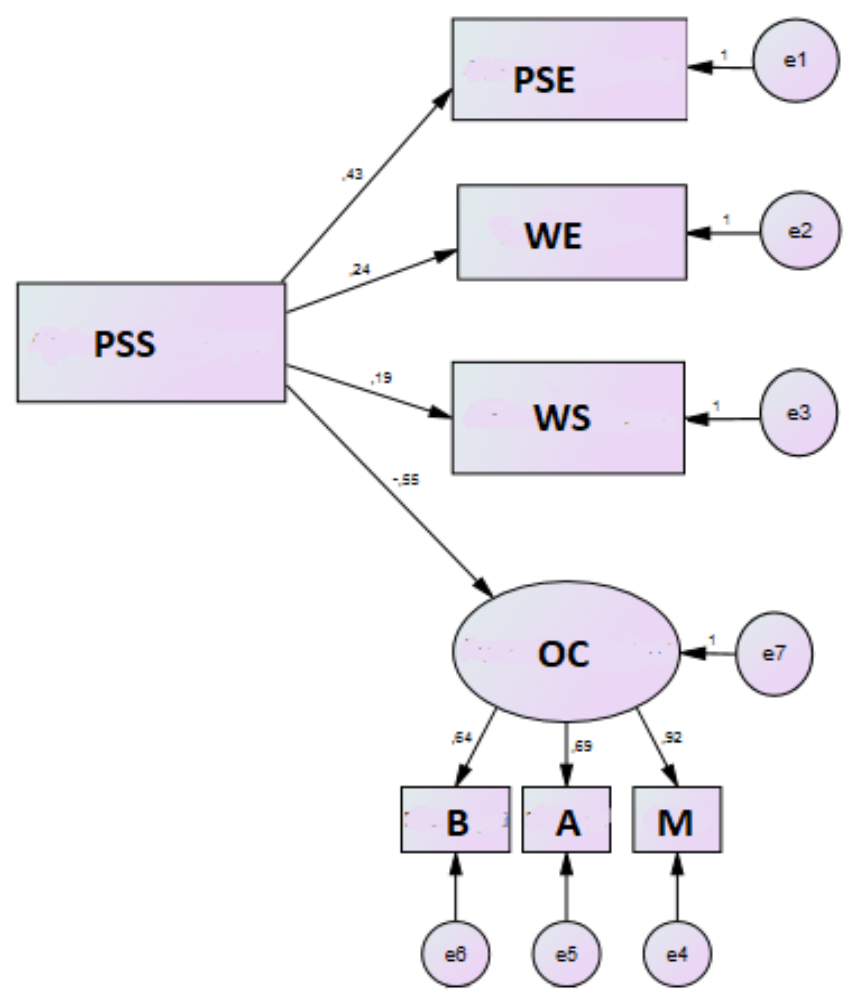

Figure 4. Graphical representation of the structural equation model.

Table 7 shows the fit index values for the structural equation model.

Table 7. Goodness of fit values for the structural equation model.

\begin{tabular}{llll}
\hline Fit Index & $\begin{array}{l}\text { Structural Equation } \\
\text { Model }\end{array}$ & Good Fit Criteria & Acceptable Fit Criteria \\
\hline$\chi^{2 /}(\mathrm{df})$ & $37,69 /(14)=$ & $0 \leq \chi^{2} \leq 3$ & $3<\chi^{2} \leq 5$ \\
RMSEA & 2,69 & $0 \leq \mathrm{RMSEA} \leq 0,05$ & $0,05<\mathrm{RMSEA} \leq 0,08$ \\
TLI $/ \mathrm{NNFI}$ & 0.063 & $0,97 \leq \mathrm{TLI} \leq 1,00$ & $0,95 \leq \mathrm{TLI}<0,97$ \\
CFI & 0.95 & $0,97 \leq \mathrm{CFI} \leq 1,00$ & $0,95 \leq \mathrm{CFI}<0,97$ \\
NFI & 0.97 & $0,95 \leq \mathrm{NFI} \leq 1,00$ & $0,90 \leq \mathrm{NFI}<0,95$ \\
AGFI & 0.96 & $0,90 \leq \mathrm{AGFI} \leq 1,00$ & $0,85 \leq \mathrm{AGFI}<0,90$ \\
GFI & 0,93 & $0,95 \leq \mathrm{GFI} \leq 1,00$ & $0,90 \leq \mathrm{GFI}<0,95$ \\
\hline
\end{tabular}

Table 7 depicts that the fit index values are good or acceptable (Byrne, 2013; SchermellehEngel, Moosbrugger \& Müller, 2003). According to these results, it is perceived that the structural equation model is verified. The findings in Table 8 relate to the established structural equation model. 
Table 8.Effect levels of the paths of variables related to structural equation model.

\begin{tabular}{|c|c|c|c|}
\hline & $\begin{array}{l}\text { Perceived Supervisor } \\
\text { Support }\end{array}$ & $\begin{array}{l}\text { Perceived Supervisor } \\
\text { Support }\end{array}$ & $\begin{array}{l}\text { Organizational } \\
\text { Cynicism }\end{array}$ \\
\hline & Direct Effect & Indiect Effect & Direct Effect \\
\hline Organizational Cynicism & $-0,55$ & 0,00 & 0,00 \\
\hline Beh. Cyn. & 0,00 & $-0,35$ & 0,64 \\
\hline Aff. Cyn. & 0,00 & $-0,37$ & 0,69 \\
\hline Cog. Cyn. & 0,00 & $-0,50$ & 0,92 \\
\hline Job Satisfaction & 0,19 & 0,00 & 0,00 \\
\hline Engagement to Work & 0,24 & 0,00 & 0,00 \\
\hline Perceived School Effectiveness & 0,43 & 0,00 & 0,00 \\
\hline
\end{tabular}

Looking at Table 8, it is comprehended that the direct effect of perceived supervisor support on organizational cynicism is -0.55 . It can be noticed in Table 8 that the direct effect of perceived supervisor support on job satisfaction is 0.19 , the direct effect on perceived school effectiveness is 0.43 and finally the direct effect on work engagement is 0.24 .

The indirect effect of perceived supervisor support on organizational cynical attitude behavioral cynicism sub-factor was -0.35 , the indirect effect on affective cynicism sub-factor was -0.37 and the indirect effect on cognitive cynicism sub-factor was -0.50. It was grasped that the subfactor of organizational cynicism, which directly affects the organizational cynic attitude at the highest level, is the cognitive sub-factor with the effect level of 0.92 . The sub-factor that directly affects the lowest level is the behavioral sub-factor with 0.64 effect level.

\section{Sub problem}

The sub problem in the research is this: "Is there a statistically significant relationship between organizational cynic attitude and perceived supervisor support, perceived school effectiveness, work engagement and job satisfaction among teachers?"

Table 9 manifests the results of Pearson correlation analysis of the relationship between organizational cynic attitude and perceived supervisor support, perceived school effectiveness, work engagement and job satisfaction among teachers.

Table 9.The results of Pearson correlation analysis of the relationship between organizational cynic attitude and perceived supervisor support, perceived school effectiveness, work engagement and job satisfaction among teachers.

\begin{tabular}{llllll}
\hline \multirow{2}{N}{$=438$} & & $\begin{array}{l}\text { Cognitive } \\
\text { Cynicism }\end{array}$ & $\begin{array}{l}\text { Affective } \\
\text { Cynicism }\end{array}$ & $\begin{array}{l}\text { Behavioral } \\
\text { Cynicism }\end{array}$ & $\begin{array}{l}\text { Organizational } \\
\text { Cynicism }\end{array}$ \\
\hline \multirow{2}{*}{ Perceived Supervisor Support } & $\mathrm{r}$ & $-0,50^{*}$ & $-0,36^{*}$ & $-0,37^{*}$ & $-0,49^{*}$ \\
& $\mathrm{p}$ &, 000 &, 000 &, 000 &, 000 \\
\hline \multirow{2}{*}{ Perceived School Effectiveness } & $\mathrm{r}$ & $-0,46^{*}$ & $-0,34^{*}$ & $-0,40^{*}$ & $-0,47^{*}$ \\
& $\mathrm{p}$ &, 000 &, 000 &, 000 &, 000 \\
\hline \multirow{2}{*}{ Work Engagement } & $\mathrm{r}$ & $-0,14^{*}$ & $-0,21^{*}$ & $-0,27^{*}$ & $-0,24^{*}$ \\
& $\mathrm{p}$ &, 001 &, 000 &, 000 &, 000 \\
\hline \multirow{2}{*}{ Job Satisfaction } & $\mathrm{r}$ & $-0,15^{*}$ & $-0,24^{*}$ & $-0,21^{*}$ & $-0,23^{*}$ \\
& $\mathrm{p}$ &, 001 &, 000 &, 000 &, 000
\end{tabular}

${ }^{*} \mathrm{p}<, 05$

When Table 9 is pondered, it is discerned that there is a negatively significant relationship between perceived supervisor support and organizational cynic attitude according to $\mathrm{r}(438)=$ $-0.49, \mathrm{p}=, 000<0.05$. It was observed that there was a negatively moderate significant 
relationship between perceived supervisor support and cognitive cynic attitude sub-factor according to $\mathrm{r}(438)=-0.50, \mathrm{p}=, 000<, 05$, a significant near-intermediate negative relationship between perceived supervisor support and affective cynic attitude sub-factor according to $\mathrm{r}_{(438)}=-0,36, \mathrm{p}=, 000<, 05$ and a significant near-intermediate negative relationship between perceived executive support and behavioral cynic attitude sub-factor according to $r$ $(438)=-0.37, \mathrm{p}=, 000<, 05$.

When Table 9 is examined, it is recognized that there is a negatively moderate significant relationship between perceived school effectiveness and organizational cynic attitude according to $\mathrm{r}(438)=-0.47, \mathrm{p}=, 000<, 05$. It is apprehended that there is a negatively moderate significant relationship between perceived school effectiveness and cognitive sub-factor of organizational cynicism according to $\mathrm{r}(438)=-0.46, \mathrm{p}=, 000<, 05$, a significant relationship above negative low level between perceived school effectiveness and affective sub-factor according to $\mathrm{r}_{(438)}=-0,34, \mathrm{p}=, 000<, 05$ and a negatively moderate significant relationship between perceived school effectiveness and behavioral sub-factor according to $\mathrm{r}(438)=-0,40$, $\mathrm{p}=, 000<, 05$.

When Table 9 is gone through, it is cognized that there is a negatively low level of significant relationship between work engagement and organizational cynic attitude compared to $\mathrm{r}(438)=$ $-0.24, p=, 000<, 05$. It is discovered that there is a negatively low level significant relationship between work engagement and organizational cynicism sub-factor of cognitive cynic attitude compared to $\mathrm{r}(438)=-0.14, \mathrm{p}=, 000<, 05)$, between work engagement and affective cynic attitude sub-factor compared to $\mathrm{r}(438)=-0.21, \mathrm{p}=, 000<, 05$, and between work engagement and behavioral cynic attitude sub-factor compared to $\mathrm{r}(438)=-0.27, \mathrm{p}=, 000<, 05$.

When Table 9 is evaluated, it is elucidated that there is a negatively low level significant relationship between job satisfaction and organizational cynic attitude compared to $\mathrm{r}(438)=$ $0.23, \mathrm{p}=, 000<, 05$. It is interpreted that, there is a negatively low-level relationship between job satisfaction and cognitive cynic attitude sub-factor according to $r(438)=-0.15, p=, 000$ $<, 05$, between job satisfaction and affective cynic attitude sub-factor according to $\mathrm{r}(438)=$ $0.24, \mathrm{p}=, 000<, 05$ and between job satisfaction and behavioral cynic attitude sub-factor according to $\mathrm{r}(438)=-0.21, \mathrm{p}=, 000<, 05$.

\section{Discussion}

Depending on the validation of the model, it is rightful to declare that perceiving supervisor support will improve work engagement and job satisfaction among teachers, wherefore increasing teachers' performances, job motivations, and teachers will make more efforts to develop and improve them. As a matter of fact, there are studies showing the positive relationship between perceived supervisor support and job performance and job satisfaction (Chiang \& Hsieh, 2012; Ingersoll, 2001; Littrell, Billingsley \& Cross, 1994; Park, Kang \& Kim, 2018; Paterson, Luthans \& Jeung, 2014; Sahin, 2013; Sahin \& Dursun, 2009; Talukder, Vickers $\&$ Khan, 2018; Tillman \& Tillman, 2008). Teachers who feel supervisor support will be able to contribute more to the development of their schools since they will be more committed to their organizations. This result will have a positive effect on the effectiveness level of the school and teachers' perceptions about it. When the literature was examined, it was found that school principals in effective schools had determined and goal-oriented leadership skills, participatory approach and professional leadership characteristics (Sammons, Hillman \& Mortimore, 1995). It can be theorized that if teachers perceive that their school is an effective organization, they will engage in their work and achieve job satisfaction and they will have a positive attitude 
towards their schools, in other words, organizational cynic attitude in teachers will be prevented.

Quality in education is influenced by plenty of variables. Nonethless, it can be put forward that the quality of teachers is the most powerful and determining factor among the factors affecting quality in education. School administrators are also responsible for the professional development and learning of teachers (Evers \& Eacott, 2016). It can be contemplated that teachers who perceive their support from the school principal will be successful in developing themselves and their schools. It can also be envisioned that this perception will enable teachers to solve the problems they face in their work and personal lives more easily.

In the study, it was concluded that teachers' perceived supervisor support significantly predicted school effectiveness perception, engagement to work, job satisfaction and organizational cynic attitude. In the literature, studies with concordant results were identified. When related studies were reviewed, the following results were reached: Perceived supervisor support predicts emotional commitment to the organization (Eisenberger, Stinglhamber, Vandenberghe, Sucharski \& Rhoades, 2002; Yasar, Emhan \& Ebere, 2014), motivates the employee and acts as an intermediary for career development of the employee (Tan, 2008), increases the frequency of organizational behavior (Ozdemir, 2010), is a mediating variable between school principals' use of power resources and corporate citizenship behavior (Ozdemir Demirel, 2012), mediates the relationship between organizational commitment and organizational performance (Emhan, Kula \& Tongur, 2013), affects job satisfaction (Ingersoll, 2001; Littrell, Billingsley \& Cross, 1994; Sahin, 2013; Sahin \& Dursun, 2009; Tillman and Tillman, 2008), is important for teachers to be motivated and successful in their studies (Ada, Akan, Ayik, Yildirim \&Yalcin, 2013) fosters emotional and behavioral development of teachers (Argon, 2014), predicts the psychological well-being of teachers at a low level (Erturk, Keskinkilic Kara \& Zafer Gunes, 2016), partially mediates the positive relationship between organizational justice perception and emotional commitment to the organization ( $\mathrm{Li}$, Castaño \& Li, 2018), has a negative impact on intention to leave job through self-efficacy and has a positive direct effect on performance (Afzal, Arshad, Saleem \& Farooq, 2019), directly affects the school principal's perception of trust in teachers and organizational justice and also indirectly impacts the perception of organizational justice through the school principal's perception of trust in teachers (Atik, Demirtas \& Aksoy, 2019). The results of this study and the related studies underpin that perceived supervisor support is a variable with positive effects on the quality of teachers and the quality of education and henceforward the quality of the education system.

The result that there are negatively different levels of relationship between teachers' organizational cynic attitudes and their perceptions of supervisor support and school effectiveness, and their engagement with work and job satisfaction is an expected result and can be interpreted as follows: As teachers' organizational cynic attitudes increase, their perceptions of executive support and school effectiveness decrease and so do their levels of engagement and job satisfaction. In the literature, there are studies with similar results to those of this study. Kilic and Burgaz (2014) and Yildiz (2013) underlined that there is a negative relationship between organizational cynicism and organizational commitment among teachers. In the studies of Amasrali and Aslan (2017), it was highlighted that there was a positive significant relationship between teachers' organizational cynic attitudes and their feelings of exhaustion. 


\section{Conclusion}

This study gives a different dimension to the literature in terms of revealing the proposed model and the analysis of the relationship between these variables with the structural equation model.

In the study, high fit goodness values were reached for the structural equation model and the model was verified accordingly. It was unearthed that the model which was formed as a result of these fit indexes had good and acceptable fit. When the significance of the relationships between the variables in the model was dissected, significant relationships were uncovered between perceived supervisor support and perception of school effectiveness, work engagement, job satisfaction, and organizational cynic attitude. As a result of the validation of the model, it was deduced that the perceived supervisor support of teachers significantly predicted school effectiveness perception, engagement to work, job satisfaction and organizational cynic attitude. When the levels of effects in the form of direct effects are examined, it is disclosed that the perceived supervisor support among teachers is positive on school effectiveness perception, engagement to work and job satisfaction; and negative on organizational cynic attitude. In the model, it was monitored that the strongest direct effect of perceived executive support was on perceived school effectiveness, and the least positive direct effect was on job satisfaction.

Another finding of the study is that there are negatively different levels of relationship between teachers' organizational cynic attitudes and their perceptions of supervisor support and school effectiveness, and their engagement with work and job satisfaction.

In line with the results obtained from this study, practitioners may be recommended the following:

- School principals should support teachers in their professional work and in solving their work or private life problems. Because through the findings in this study it was decided that the perceived supervisor support of teachers significantly predicted school effectiveness perception, engagement to work, job satisfaction and organizational cynic attitude.

- The factors that cause organizational cynical attitude should be determined in teachers and ways to eliminate these should be considered because in this study, it appeared that there are negatively different levels of relationship between teachers' organizational cynic attitudes and teachers' perceptions of supervisor support and school effectiveness, and their engagement with work and job satisfaction.

The researchers are recommended the following:

- Structural equation modeling studies can be made on the models to be proposed by considering the other variables related to teachers' perceived administrator support may affect.

- In this study, data was collected from 664 teachers. The study can be repeated with a larger sample group.

- Although the scales used in the research are scales with high reliability and validity, the research can be repeated using different scales and the results obtained can be compared.

\section{References}

Abraham, R. (2000). Organizational cynicism, bases consequences genetic. Social and General Psychology Monographs, 126(3), 269-292. 
Acar, F. M. (2016). Investigation of the burnout and the job satisfaction levels of pre-school teachers in terms of different variables.(Unpublished master dissertation). Cag University, Mersin, Turkey.

Ada, S. (2014). Okul yönetiminde personel eğitim ve işletmecilikle ilgili işler [Staff education and business affairs in school management]. In, Vehbi Çelik (Ed.), TürkEğitimSistemiveOkulYönetimi [Turkish Education System and School Management] (pp. 143-180). Ankara: PegemPubl.

Ada, S., Akan, D., Ayik, A., Yildirim, İ. \&Yalcin, S. (2013). Motivation factors of teachers. Atatürk University Journal of Graduate School of SocialSciences, 17(3), 151-166.

Afzal, S., Arshad, M., Saleem, S. \& Farooq, Ö. (2019). The impact of perceived supervisor support on employees' turnover intention and task performance: mediation of selfefficacy. Journal of Management Development, https://doi.org/10.1108/JMD-032019-0076

Alanoglu, M. (2019). Analysis of the relationships between perceived school principal management styles and teachers' participation in decision making, organizational justice, job satisfaction and burnout perceptions. (Unpublished doctoral dissertation). Firat University, Elazig, Turkey.

Amasrali, A. \& Aslan, H. (2017). The relationship between organizational cynicism and burnout levels of secondary school and high school mathematics teachers. Mehmet Akif Ersoy University Journal of Education Faculty, 43, 64-92.

Andersson, M. L. (1996). Employee cynicism: An examination using a contract violation framework. Sage Journals, 49(11), 1395-1418.

Argon, T. (2014). Supporting human resources in educational institutions: teacher views on administrator support. Journal of Human Sciences, 11(2), 691-729.

Atik, S., Demirtas, H. \& Aksoy, M. (2019). The mediating effect of the trust of managers in teachers in the relation between manager support and organizational justice. Journal of Teacher Education and Educators, 8 (3), 265-280.

Babin Barry, J. \& Boles James, S. B. (1996). The effects of perceived co-worker involvement and supervisor support on service provider role stress, performance and job satisfaction. Journal of Retailing, 72 (1), 60.

Bal, E. A. (2009). Bir pozitif psikoloji kavramı olarak işe gönülden adanma ve insan kaynakları açısından önemi [Dedication to work as a positive psychology concept and its importance for human resources]. 17. NationalManagement and Organization Congress (21-23 May, Eskisehir, Turkey) Full Text Book, 546-552.

Balci, A. (2011). Etkili okul ve okul geliştirme kuram uygulama ve araştırma [Effective school and school development theory practice and research]. Ankara: PegemPubl.

Bilgic, A. M. (2018). Examining the relationship between devotion to the profession and intention to quit: An application at Adlyaman University.(Unpublished master dissertation).HasanKalyoncu University, Gaziantep, Turkey.

Bogler, R. (2002). Two profiles of school teachers: a discriminant analysis. Teaching and Teacher Education, 18(6), 665-673.

Brandes, P, Dharwadkar, R. \& Dean, J. W. (1999). Does organizational cynicism matter? employee and supervisor perspectives on work outcomes. Eastern Academy of Management Proceedings, 150-153.

Byrne, B. M. (2013). Structural equation modeling with LISREL, PRELIS, and SIMPLIS: Basic concepts, applications, and programming. New York: Psychology Press.

Can, N. (2004). Development of teachers and effective teacher behavior. Erciyes University Journal of the Social Sciences, 16(1), 103-119.

Chiang, C.F. \& Hsieh, T.S. (2012), The impacts of perceived organizational support and psychological empowerment on job performance: the mediating effects of 
organizational citizenship behavior. International Journal of Hospitality Management, 31 (1), 180-190.

CakmakOtluoglu, K. Ö. (2012). Protean and boundaryless career attitudes and organizational commitment: the effects of perceived supervisor support. Journal of Vocational Behaviour, 80, 638-646.

Dean, J. W., Brandes, P. \&Dharwadker, R. (1998). Organizational cyncism. The Academy of Management Review, 23(2), 341-352.

Demirtas, Z. (2010). Teachers' job satisfaction levels. Procedia Social and Behavioral Sciences, 9, 1069-1073.

Demirtas, Z. \&Alanoglu, M. (2015). The relationship between participation in decisionmaking of teachers and job satisfaction. Ahi Evran University Journal of Kirsehir Faculty of Education 16(2), 83-100.

Dos, İ. (2013). Etkili okul ve yönetimi [Effective school and its management]. In, Niyazi Can (Ed.) Kuram ve Uygulamada Ĕ̈itim Yönetimi [Educational management in theory and practice] (pp. 217-264. Ankara: PegemA Publ.

Dugguh, S. I. and Ayaga, D. (2014). Job satisfaction theories: traceability to employee performance in organizations. Journal of Business and Management, 16(5), 11-18.

Eisenberger, R., Stinglhamber, F., Vandenberghe, C., Sucharski, I. L., \& Rhoades, L. (2002). Perceived supervisor support: Contributions to perceived organizational support and employee retention. Journal of Applied Psychology, 87, 565-573. https://doi.org/ck75qx

Emhan, A., Kula, S. \&Töngür, A. (2013). Analysis of relationship among manager support, organizational commitment, organizational performance, and burnout with structural equation model: the case of government sector. Hacettepe University Journal of Economics and Administrative Sciences, 31(1).doi: 10.17065/huniibf.103655

Ercek, M. K. (2018). The effect of teachers' school safety perceptions on organizational confidence and professional commitment in secondary schools.(Unpublished doctoral dissertation). Dicle University, Diyarbakir, Turkey.

Erturk, A., Keskinkilic Kara, S.B. \& Zafer Gunes, D. (2016). Emotional labor and psychological well-being: perception of administrative support as a predictor. Abant İzet Baysal University Journal of Faculty of Education, 16(4), 1723-1744.

Evers, C. W., \&Eacott, S. (Eds.). (2016). New directions in educational leadership theory. New York: Routledge, Taylor \& Francis Group.

Guchiat, P., Paşamehmetoğlu, A, \& Dawson, M. (2014). Perceived supervisor and co-worker support for error management: impact on perceived psychological safety and service recovery performance. International Journal of Hospitality Management, 41, 28-37.

Hackman, J. R. \& Oldham, G. R. (1976). Motivation through the design of work: test of a theory. Organizational Behavior and Human Performance, 16(2), 250- 279.

Handsome, J. (2009). The relationship between leadership style and job satisfaction. (Unpublished doctoral dissertation). Walden University, Minnesota, USA.

Ho, C.L. \& Au, W.T. (2006). Teaching satisfaction scale: measuring job satisfaction of teachers. Educational and Psychological Measurement, 66, 172-185.

Hoy, W. K. (2009). School effectiveness index (SE-Index). Retrieved from https://www.waynekhoy.com/schooleffectiveness/on 21.01.2020

Hoy, W. K. ve Ferguson, J. (1985). A theoretical framework and exploration of organizational effectiveness in schools. Educational Administration Quarterly,21,117-134.

Hoy, W. K., Tarter, C. J., \& Kottkamp, R. B. (1991). Open schools/healthy schools: Measuring organizational climate. Beverly Hills, CA: Sage.

Hoy, W. K. \& Miskel, C. G. (1996). Educational administration: Theory, research, and practice, 5th edition. New York: McGraw-Hill. 
Hoyle, R.H. (1995). Structural equation modeling: concepts, issues, and application. London: SAGE Publ.

Ingersoll, R. M. (2001). Teacher turnover and teacher shortages: an organizational analysis. American Educational Research Journal, 38(3), 499-534.

Kalagan, G. (2009). The relationship between research assistants' perceptions of organizational support and organizational cynicism (Unpublished master dissertation). Akdeniz University, Antalya, Turkey.

Kilic, S. (2013). Sampling methods. Journal of Mood Disorders, 3(1), 44-46.

Kilic, S. \& Burgaz, B. (2014). The relationship between the organizational cynicism and organizational commitment levels of primary school teachers. Mediterranean Journal of Educational Research, 16, 17-34.

Kottke, J. L., \& Sharafinski, C. E. (1988). Measuring perceived supervisory and organizational support. Educational and Psychological Measurement, 48(4), 1075-1079. https://doi.org/10.1177/0013164488484024.

Li, Y., Castaño, G. \& Li, Y. (2018). Perceived supervisor support as a mediator between Chinese university teachers' organizatıonal justice and affective commitment. Social Behavior and Personality, 46(8):1385-1396. DOI: $10.2224 /$ sbp.6702

Littrell, P. C., Billingsley, B. S., \& Cross, L. H. (1994). The effects of principal support on special and general educators' stress, job satisfaction, school commitment, health, and intent to stay in teaching. Remedial and Special Education, 15(5), 297310. https://doi.org/10.1177/074193259401500505

Ma, X. \& MacMillan, R. B. (1999). Influences of workplace conditions on teachers' job satisfaction. Journal of Educational Research, 93(1), 39-47.

Makela, K. (2014). PE teachers' job satisfaction, turnover, and intention to stay or leave the profession. (Unpublished doctoral dissertation). University of Jyväskylä (Studies in Sport, Physical Education and Health), Jyväskylä, Finland.

May, D. R., Gilson, R. L., \& Harter, L. M. (2004). The psychological conditions of meaningfulness, safety and availability and the engagement of the humanspirit at work. Journal of Occupational and Organizational Psychology (77), 11-37.

Melián-González, S. (2016). An extended model of the interaction between work-related attitudes and job performance. International Journal of Productivity and Performance Management, 65 (1), 42-57.

Miles, W. L. (2010). Correlatıonal Study of Leadership Style and Teacher Job Satısfaction in Two Head Start Programs. (Unpublished doctoral dissertation). Capella University, Minnesota, USA.

Miskel, C. G., Fevurly, R. \& Stewart, J. (1979). Organizational structures and processes, perceived school effectiveness, loyalty, and job satisfaction. Educational Administration Quarterly, 15(3), 97-118.

Mosadeghrad, A. M. \&Ferdosi, M. (2013). Leadership, job satisfaction and organizational commitment in healthcare sector: proposing and testing a model. Mat Soc. Med, 25(2), 121-126.

Mott, P. E. (1972). The characteristics of effective organizations. New York: Haper\& Row.

Neves, P. (2011). Building commitment to change: The role of perceived supervisor support and competence. European Journal of Work and Organizational Psychology, 20, 437450. https:// doi.org/dj8kbt

Ozdemir, A. (2010). The relationship of perceived superior support and individualism collectivism with organizational citizenship behaviors in primary schools. Educational Administration: Theory and Practice, 16 (1), 93-112.

Ozdemir, S. (2000). Eğitimde örgütsel yenileşme [Organizational innovation in education]. Ankara: Pegem A Publ. 
Ozdemir Demirel, G. (2012). The styles of school principals' using power sources and the relationship between principle support and citizenship behaviour.(Unpublished master dissertation).Gazi University, Ankara.

Ozkalp, E. \& Meydan, B. (2015). Analysis of the reliability and validity of the work engagement scale developed by Schaufeli and Bakker in Turkish. Is, Guc: The Journal of Industrial Relations \& Human Resources, 17(3), 4-19.

Ozkuk, Z. (2017). Perceived administrator support and teachers' views on loneliness in business life (Unpublished master dissertation). Abant Izzet Baysal University, Bolu.

Park, S., Kang, H. S. \& Kim, E. J. (2018), The role of supervisor support on employees' training and job performance: an empirical study. European Journal of Training and Development, 42 (1/2), 57-74.

Paterson, T.A., Luthans, F. \& Jeung, W. (2014). Thriving at work: impact of psychological capital and supervisor support. Journal of Organizational Behavior, 35 (3), 434-446.

Rhoades, L., Eisenberger, R., \& Armeli, S. (2001). Affective commitment to the organization: The contribution of perceived organizational support. Journal of Applied Psychology, 86, 825-836. https://doi.org/fdsjxd

Roberts, D. R., \& Davenport, T. O. (2002). Job engagement: why it's 1mportant and how to improve it. Employment Relations Today, 29(3), 21-29.

Román Calderón, J. P., Battistelli, A, \&Odoardi, C. (2013). Work engagement as mediator between perceived participation, supervisor support and altruistic behaviors: empirical results from the Italian social enterprise sector. UniversitasPsychologica, 12(3), 899909.

Sammons, P., Hillman, J. \& Mortimore, P. (1995). Key characteristics of effective schools: a review of school effectiveness research. Paper presented at an internal seminar for Ofsted, London: Institute of Education, 1-71.

Sarıkaya, Ş. (2019). The perception of organizational trust and organizational support as predictors of teachers' job satisfaction .(Unpublished master dissertation). İstanbul Sabahattin Zaim University, İstanbul, Turkey.

Sarkisian, N., Bhate, R. \& Lee, J. (2011). Effects of country \& age on work engagement, job satisfaction \& organizational commitment among employees in the United States. The Sloan Center on Aging \& Work at Boston College, 29.

Schaufeli, W. B. (2015). Engaging leadership in the job demands-resources model. Career Development International, 20(5), 446-463.

Schaufeli, W. B. \& Bakker, A. B. (2003). Test manual for the Utrecht work engagement scale. (Unpublished manuscript). Utrecht University, Netherlands. Retrieved from http://www.schaufeli.com

Schermelleh-Engel, K., Moosbrugger, H., \& Müller, H. (2003). Evaluating the fit of structural equation models: Tests of significance and descriptive goodness-of-fit measures. Methods of psychological research online, 8(2), 23-74.

Sloan, M.M. (2012). Unfair treatment in the workplace and worker well-being: the role of coworker support in a service work environment. Work and Occupations, 39 (1), 3-34.

Stinglhamber, F., \& Vandenberghe, C. (2003). Organizations and supervisors as sources of support and targets of commitment: A longitudinal study. Journal of Organizational Behavior, 24, 251-270. https://doi.org/bdx9kp

Sahin, H. \& Dursun, A. (2009). Job satisfaction of preschool teachers. Mehmet Akif Ersoy University Journal of Education Faculty, 9(18), 160-174.

Sahin, İ. (2013). Job satisfaction levels of teachers. YuzuncuYil UniversityJournal of Education Faculty, 1, 142-167

Simsek, Ö. F. (2007). Yapısal eşitlik modellemesine giriş temel ilkeler ve LISREL uygulamaları. Ankara: Ekinoks. 
Sisman, M. (2012). Eğitimde mükemmellik arayışl, etkili okullar [The pursuit of excellence in education, effective schools]. Ankara: Pegem A Publ.

Sisman, M. \& Turan, S. (2005). Eğitim ve okul yöneticiliği el kitabı [Education and school management handbook]. Ankara: Pegem A Publ.

Tan, F. (2008). Linking career development practices to turnover intention: the mediator of perceived organizational support. Journal of Business and Public Affair, 2 (1), 5-26.

Talukder, A., Vickers, M. \& Khan, A. (2018). Supervisor support and work-life balance: impacts on job performance in the Australian financial sector. Personnel Review, 47 (3), 727-744.

Tillman, W. R. \& Tillman, C. J. (2008). And you thought it was the apple: a study of job satisfaction among teachers. Academy of Educational Leadership Journal, 12(3), 1-18.

Turgut, T. (2011). A passion for work: workload, flexible working hours, supervisor support, and relationships with work-family conflict. Atatürk University Journal of Economics and Administrative Sciences, 25 (3-4), 155-179.

Yapicikardeşler, E. (2007). Examining the relationship between teachers' value orientations and job satisfaction. (Unpublished master dissertation).Yeditepe University, İstanbul, Turkey.

Yasar, M. F., Emhan, A. \&Ebere, P. (2014). Analysis of organizational justice, supervisor support, and organizational commitment: A case study of energy sector in Nigeria. Journal of Business Studies Quarterly, 5, 37-46.

Yildirim, İ. (2015). An analysis of school managers' personality and locus of control traits in regard to teachers' job satisfaction and effectiveness of schools. (Unpublished doctoral dissertation). Atatürk University, Erzurum, Turkey.

Yildiz, K. (2013). The relationship between organizational commitment and organizational cynicism and organizational dissent. Turkish Studies, 8/6, 853-879.

Yoon, J. \& Lim, J. C. (1999). Organizational support in the workplace: The case of Korean hospital employees. Human Relations, 52, 923-945. 